\title{
Why Parallel TRAdE MAY RAISE PRODUCERS PROFITS
}

\author{
HORST RAFF \\ NICOLAS SCHMITT
}

CESIFO WORKING PAPER NO. 1503

CATEgORY 7: TRADE POLICY

JULY 2005

\footnotetext{
An electronic version of the paper may be downloaded

- from the SSRN website:

www.SSRN.com

- from the CESifo website: www.CESifo.de
} 


\title{
Why Parallel Trade May Raise Producers PROFITS
}

\begin{abstract}
This paper shows that a manufacturer may benefit from parallel trade. In addition to an intuitive condition about the effect of demand shocks, this occurs when competitive retailers must order inventories before they know the realization of demand and for products whose sale value drops at the end of the demand period. For these types of products, letting retailers trade unsold inventories generally results in larger orders placed with the manufacturer, higher manufacturer profit and higher consumer surplus. The model provides a simple explanation as to why the volume of parallel trade is now very large and accepted by manufacturers for some products such as automobiles, clothes, toys, consumer electronics, musical recordings, cosmetics and perfumes.
\end{abstract}

JEL Code: F12.

Keywords: parallel trade, distribution.

Horst Raff

Department of Economics

Chair of Microeconomics

Christian-Albrechts-University

Olshausenstr. 40

24098 Kiel

Germany

raff@econ-theory.uni-kiel.de
Nicolas Schmitt

Department of Political Economics

University of Geneva

Bd du Pont d'Arve 40

1211 Geneva 4

Switzerland

schmitt@ecopo.unige.ch

We thank Frank Stähler and seminar participants for useful comments. The authors acknowledge financial support from the Social Sciences and Humanities Research Council of Canada and from the Transcoop Program of the Alexander-von-Humboldt Foundation and the German Ministry of Education. 


\section{Introduction}

The purpose of this paper is to demonstrate that circumstances exist under which it pays a manufacturer to allow distributors (hereafter called retailers) to engage in parallel trade, that is trade that is not directly controlled by the trademark, copyright or patent owner, generally the manufacturer himself. Moreover, we show that under these circumstances parallel trade- sometimes also referred to as gray markets - is typically welfare improving.

These results arise when four conditions are met. The first two are about the nature of the product: retailers must place orders before they know the state of demand, and the products have little value at the end of the demand period (or equivalently, it is costly to maintain them as inventories). The other two conditions are about the demand: the states of demand must be different across markets, and different states of demand affect the quantity demanded rather than consumer's willingness to pay for the products.

There are several markets for which these conditions are met. In the markets for automobiles, motorcycles and clothes manufacturers have to introduce new models frequently. In the toy market, products have very narrow and well-defined demand periods (e.g., pre-Christmas season). In all these cases, the value of the products decreases significantly at the end of the demand period. Moreover, many goods are not produced on a just-in-time inventory basis and exploiting scale economies often requires significant lags between production and sales. In other words, orders must be placed well before the relevant demand period. This often leads to errors in forecasting the future strength of demand and thus ex post to incentives to ship unsold inventories to markets where demand turns out to be higher than expected.

To understand why a manufacturer may have an incentive to allow this type of parallel trade, suppose he does not and is able to effectively ban parallel trade. Retailers may then be stuck with significant unsold inventories, in which case they have a strong incentive to lower prices. Competition among retailers might even force the price down to zero, since inventories are essentially sunk investments. But if they anticipate a possible loss, retailers will be reluctant to order large inventories. Banning parallel trade may thus be detrimental to the manufacturer's profitability. Allowing parallel trade, on the other hand, may provide a simple mechanism to keep retail prices from falling dramatically when the state of the demand turns out to be low and thus give retailers an incentive to place larger orders than they otherwise would. This is not a trivial issue since parallel trade provides additional 
sales opportunities for those retailers that can export but at the same time lowers those of retailers that face competition from imports. We hence must show that parallel trade leads to larger total orders. The four conditions mentioned above make sure that this is indeed the case and that parallel trade raises the manufacturer's profit over a wide range of parameters. Also note that our reasoning does not rely on an insurance argument - we assume throughout that retailers are risk neutral.

Is there evidence that manufacturers like parallel trade? Data on parallel trade are notoriously hard to come by, simply because trade statistics do not distinguish between authorized and unauthorized intermediaries (Maskus, 2000). However, the volume of parallel trade has simply become too large to argue seriously that manufacturers either do not know of its existence or know about it but are unable to stop it even if it lowers their profitability. In other words, manufacturers must benefit from parallel trade at least in some markets. ${ }^{1}$ This view is held by several experts. For instance, Lipner (1990, p.4) writes "[..] some manufacturers, while publicly opposed to gray market sales of their products, privately do little to inhibit their flow and in some instances even go so far as to encourage these transactions." Similarly, a report prepared for the EU Commission (NERA, 1999, p.11) states "[s]ome parallel trade, however, seems to be beneficial to the trademark owner. [..] If, for example, there is for some reason over-production in the source country, and the manufacturer would otherwise be left with an unsold stock, parallel trade may be a means to raise profits through additional sales. Another example is goods such as clothing which are subject to fashion waves. Previous season's clothing in one country can still yield useful revenues in other countries". Furthermore, a "dealer might [..] have over ordered, or might have excess quantities of an older or out-of-date version of the goods" (Lipner, 1990, p7). ${ }^{2}$

The North American automobile market is a good case to keep in mind. Retailers selling new automobiles must sign a contract with manufacturers forbidding them to re-sell these cars in other countries. Yet over 200,000

\footnotetext{
${ }^{1}$ In the US, parallel imports were estimated to be worth $\$ 7-10$ billions in the mid1980s (Cespedes, Corey and Rangan, 1988); today, estimates of $\$ 20$ billion can be found (Computer Reseller News, 2001). In Europe, the volume of parallel imports varies from $5 \%$ of sales in markets like appliances, motorcars and consumer electronics to nearly $15 \%$ for musical recordings, cosmetics and perfumes (NERA, 1999) and to even $25 \%$ in the UK motorcycle market (House of Commons, 1999).

${ }^{2}$ See also Cespedes et al. (1988), Computer Reseller News (2001), and House of Commons (1999).
} 
vehicles intended for the Canadian market were resold south of the border in 2001 (up from 16,000 in 1996; see Automotive News, 2002). Obviously, this no-parallel-trade clause is not enforced despite the fact that retailers face heavy penalties. ${ }^{3}$ Parallel imports arise in this market in part because of the quota system adopted by most North American manufacturers. Retailers receive a pre-determined volume allocation per model in order to force them to sell a minimum number of cars without restricting retail prices. ${ }^{4}$ The consequence is often a mismatch between demand and supply creating strong incentives for parallel trade between Canada and the US especially when a particular model sells well in one country and not in the other. ${ }^{5}$ The automobile producers could easily eliminate this unintended trade. The fact that they do not indicates that they are not particularly hurt by this trade. ${ }^{6}$

The existing literature on parallel trade has mainly focused on the issue of price discrimination (Malueg and Schwartz, 1994; Richardson, 2002; Maskus and Chen, 2002). This literature generally finds that manufacturers want to avoid parallel trade, because it interferes with their ability to segment markets and set different prices in different countries. ${ }^{7}$ The welfare effects of allowing parallel trade in these models are generally ambiguous, simply because the elimination of price discrimination may or may not be welfare improving (Tirole, 1988). We see our explanation of the role of par-

\footnotetext{
${ }^{3}$ Interestingly, this clause seems to have rarely been tested in court.

${ }^{4}$ This huge increase in parallel imports is also due to wholesale pricing policies adopted by the automobile producers in the two countries. Canadian dealers apparently benefit from lower prices than their US counterparts, because they are located in a generally thiner, weaker and more price elastic market (Automotive News, 2002).

5 "When a customer wants a car that the dealer cannot supply, the dealer has two choices [...], they can turn the customer away or they can source the car from a Canadian exporter [...]. When a new luxury car hits North American dealer lots, it can generate year-long American waiting lists; [in Canada], they just sit on the lot" (Financial Post, 2001).

${ }^{6}$ Other examples of parallel trade arise from the fact that particular models are not distributed in one country (see Automotive News, 2004a and World IT Report, 2003), or that manufacturers deliberately oversupply certain markets to keep a presence there. For instance, Mercedes-Benz wanting to keep a presence in Barbados systematically ships too many cars there that are typically re-exported to the UK. According to House of Commons (1999), this implies that the manufacturer consents to parallel trade.

${ }^{7}$ Knox and Richardson (2002) show, however, that a foreign monopoly may benefit from parallel trade when a country chooses both its tariff level and whether to allow parallel trade. Ahmadi and Yang (2000), Cosac (2002) show that parallel imports may also benefit manufacturers when they are perceived as different products with respect to the authorized products.
} 
allel trade not as a substitute to this story but as a complement. In our model, the manufacturer's incentive to allow parallel trade is particularly strong when the price elasticity of demand is similar across countries but there is uncertainty about the actual size of demand. However, if there are significant (permanent or random) differences in the price elasticity of demand across markets, a manufacturer has every incentive to keep markets segmented in order to practice (third degree) price discrimination. The manufacturer hence typically faces a trade-off-at least for the products that satisfy our conditions - between prohibiting parallel trade to practice international price discrimination and allowing parallel trade to get retailers to order more inventory. This may explain why the North American automobile manufacturers insist on a no-parallel-trade clause in their contracts with dealers, but do not always enforce it. ${ }^{8}$

Finally, our approach shows that a key to understanding parallel trade is to consider whether the incentives faced by manufacturers and retailers are aligned or not. When they are aligned, as in our paper, there is no need for manufacturers to impose (or enforce) no-parallel-trade clauses in their contracts with retailers. In this sense, the present paper brings the economic literature on parallel trade closer to the legal (including law and economics) literature where parallel trade is mainly viewed as a contractual issue between manufacturers and intermediaries (see Lipner, 1990; Gallini and Hollis, 1999).

The rest of the paper is organized as follows. In Section 2 we illustrate the main points of the paper with the help of a simple model. Section 3 contains a general model and proofs of the main results. Section 4 concludes.

\section{A Simple Model}

Consider a risk-neutral monopoly manufacturer selling to a continuum of risk-neutral retailers in two different countries, denoted $A$ and $B$. In turn these competitive retailers sell to consumers. Retailers must deal with two

${ }^{8}$ Threatening retailers may be enough to limit parallel trade while secretly tolerating it. It is only during periods of very significant retail price differences between the US and Canada (whether due to a low Canadian dollar or to a demand boom in the US as during the 1999-2001 period) that manufacturers start enforcing the no-parallel-trade clause. Today the volume of parallel trade in this market has slowed down considerably (Automotive News, 2004b). 
key characteristics of the market: first, they must order and take possession of inventories before demand becomes known, and second, inventories left unsold at the end of the demand period have no value. Retailers face a constant unit cost of distribution that we normalize to zero. The manufacturer's production cost is also assumed to be zero, as is the trade cost; this implies that we do not need to specify in which country the manufacturer is located.

We denote the volume of realized sales in country $i$ by $q_{i}$. The volume of realized sales may differ from the volume ordered from the manufacturer, denoted by $x_{i}$, if after the realization of demand some goods are reexported or inventory is left unsold. Demand in country $A$ is deterministic and given by the inverse demand function $p_{A}=1-q_{A}$. The inverse demand function in $B$ is $p_{B}=1-\frac{q_{B}}{s}$, where the random variable $s$ takes the value of 1 if demand is high and $\theta<1$ if demand is low. The low state of demand occurs with probability $\lambda$. We have picked these demand functions to illustrate two points. First, parallel imports in our model occur even if the manufacturer does not price-discriminate between markets. In fact, a monopolist selling directly to consumers would set the same price in the two markets. Second, parallel imports may go in both directions, even if one country has a larger market than the other and/or one country has deterministic demand.

The game we study has the following order of moves. The manufacturer first announces a wholesale price $w_{i}$ for each market $i=A, B$ and whether retailers have the authorization to engage in parallel trade. The retailers then order inventory and, after observing the true realization of demand, decide where and how much to sell at the market-clearing price.

\subsection{No Parallel Trade}

We first derive the benchmark solution when the manufacturer does not authorize the competitive retailers to ship any inventory to the other country (no parallel trade). In this case, the two markets are completely segmented and equilibrium is the same as the solution to the flexible price game analyzed by Deneckere et al. (1997). It is straightforward to show that, in market A, $\hat{p}_{A}=\hat{w}_{A}=1 / 2, \hat{q}_{A}=\hat{x}_{A}=1 / 2$ and the manufacturer's profit is $\widehat{\pi}_{A}^{m}=1 / 4$.

Consider now market $B$. Competitive retailers have every incentive to put whatever volume they have ordered on the market at whatever price the market will support, as the product has no value (or is prohibitively costly to store) once the the demand period has ended. In particular, the retail price may effectively drop to zero when the demand turns out to be low. 
Hence there are two possibilities when the demand is low: the retail price may be positive or equal to zero. Of course, this will depend on the level of the wholesale price: if it is high enough, inventories will tend to be low leading to a positive retail price. To uncover the circumstance under which the retail price may fall to zero when the demand is low, consider each case separately.

The representative retailer's expected profit can be written as

$$
E \pi_{B}^{r}=\lambda \max \left(0,1-\frac{x_{B}}{\theta}\right) x_{B}+(1-\lambda)\left(1-x_{B}\right) x_{B}-w_{B} x_{B} .
$$

If the retail price in $B$ falls to zero in the low demand state $\left(\max \left\{0,1-\frac{x_{B}}{\theta}\right\}=\right.$ $0)$, the representative retailer earns positive revenue only when the demand is high. Since in equilibrium the retailer's expected profit is necessarily equal to zero, $x_{B}=1-\frac{w_{B}}{1-\lambda}$. The manufacturer then chooses $w_{B}$ to maximize $\Pi_{B}^{n p i}=w_{B} x_{B}$. The solution is $\widehat{w}_{B}=\frac{1-\lambda}{2}$, implying an order volume of $\widehat{x}_{B}=\frac{1}{2}\left(=\hat{x}_{A}\right)$, a retail price in the state of high demand of $\widehat{p}_{B}^{h}=\frac{1}{2}$, and a low-demand retail price of $\widehat{p}_{B}^{l}=0$. In the high-demand state retailers sell their entire inventory, i.e., $\widehat{q}_{B}^{h}=\frac{1}{2}$. Realized sales in the low-demand state are equal to $\widehat{q}_{B}^{l}=\min \left(\theta, \frac{1}{2}\right)$. Hence, the manufacturer sets a low wholesale price in order to induce retailers to order the level of inventory that would be optimal if demand turned out to be high.

If the retail price in $B$ is positive irrespective of the state of the demand $\left(\max \left\{0,1-\frac{x_{B}}{\theta}\right\}=1-\frac{x_{B}}{\theta}\right), x_{B}=\frac{\theta\left(1-w_{B}\right)}{\theta(1-\lambda)+\lambda}$ ensures that the representative retailer makes zero expected profit. The manufacturer then chooses $\tilde{w}_{B}=\frac{1}{2}$ to maximize his expected profit. This implies that $\tilde{x}_{B}=\tilde{q}_{B}=$ $\frac{\theta}{2(\theta(1-\lambda)+\lambda)}\left(<\hat{x}_{A}\right), \tilde{p}_{B}^{h}=\frac{2(\theta(1-\lambda)+\lambda)-\theta}{2(\theta(1-\lambda)+\lambda)}\left(\geq \hat{p}_{A}\right)$ and $\tilde{p}_{B}^{l}=\frac{2(\theta(1-\lambda)+\lambda)-1}{2(\theta(1-\lambda)+\lambda)}\left(\leq \hat{p}_{A}\right)$. Hence the manufacturer sets the same 'high' wholesale price he would if demand were certain to be high, but accepts that the inventories are lower than in country $A$ and therefore too low when demand turns out to be high.

When the manufacturer does not authorize parallel trade, his optimal strategy in $B$ is straightforward. Comparing profits, he chooses a high wholesale price, $\widetilde{w}_{B}=\frac{1}{2}$, when he expects the demands in the two states to be relatively similar $\left(\frac{1-\lambda}{2-\lambda} \leq \theta \leq 1\right)$ and he chooses a low wholesale price, $\widehat{w}_{B}=\frac{1-\lambda}{2}$, otherwise $\left(\theta<\frac{1-\lambda}{2-\lambda}\right)$. As a result, the manufacturer's total expected profit is

$$
\Pi^{n p t}= \begin{cases}\frac{1}{4}\left[1+\frac{\theta}{\theta(1-\lambda)+\lambda}\right] & \text { if } \frac{1-\lambda}{2-\lambda} \leq \theta \leq 1 \\ \frac{1}{4}[2-\lambda] & \text { if } \theta<\frac{1-\lambda}{2-\lambda}\end{cases}
$$




\subsection{Parallel Trade}

We now consider the case where the manufacturer allows the retailers to engage in parallel trade. The direct effect is to provide retailers in $B$ with an opportunity to sell unsold inventories in $A$ when demand is low. But this would mean more competition for retailers in A. Hence, the possibility of having to compete with parallel imports from $B$ implies that retailers in $A$ also face random (residual) demand and may end up re-exporting part of their inventory when demand in $B$ turns out to be higher than expected. Hence even with demand shocks in only one country, parallel trade may take place in either direction.

Below, we denote the volume of parallel trade originating in $B$ by $m^{j}$, where $j=h, l$ denotes the state of demand in $B$. It should be clear that when demand in $B$ is low $(j=l)$, parallel trade necessarily goes from $B$ to $A\left(m^{l}>0\right)$. However, when the demand in $B$ is high $(j=h)$, parallel trade could potentially originate in $B\left(m^{h}>0\right)$ or in $A\left(m^{h}<0\right)$. Sales in $A$ in the presence of parallel trade are equal to $x_{A}+m^{j}$, and sales in $B$ are given by $x_{B}-m^{j}$.

The expected retail profit in $B$ when $m^{h}>0$ is then equal to

$$
\begin{aligned}
E \pi_{B}^{r} & =\lambda\left\{\left(1-\frac{x_{B}-m^{l}}{\theta}\right)\left(x_{B}-m^{l}\right)+\left(1-\left(x_{A}+m^{l}\right)\right) m^{l}\right\} \\
& +(1-\lambda)\left\{\left(1-\left(x_{B}-m^{h}\right)\right)\left(x_{B}-m^{h}\right)+\left(1-\left(x_{A}+m^{h}\right)\right) m^{h}\right\}-w_{B} x_{B} .
\end{aligned}
$$

If $m^{h}<0$, the expected retail profit in $B$ is

$$
\begin{aligned}
E \pi_{B}^{r}= & \lambda\left\{\left(1-\frac{x_{B}-m^{l}}{\theta}\right)\left(x_{B}-m^{l}\right)+\left(1-\left(x_{A}+m^{l}\right)\right) m^{l}\right\} \\
& +(1-\lambda)\left(1-\left(x_{B}-m^{h}\right)\right) x_{B}-w_{B} x_{B} .
\end{aligned}
$$

We assume that the difference in demands that triggers parallel trade between the two countries is sufficiently small so that the volume traded equalizes retail prices. Hence

$$
1-\frac{x_{B}-m^{l}}{\theta}=1-\left(x_{A}+m^{l}\right) \text { or } 1-\left(x_{B}-m^{h}\right)=1-\left(x_{A}+m^{h}\right) .
$$

It follows that the volume of parallel trade is

$$
m^{l}=\frac{x_{B}-\theta x_{A}}{1+\theta} \text { or } m^{h}=\frac{x_{B}-x_{A}}{2} .
$$


Substituting (5) into (3) or (4) and setting the representative retailer's profit to zero, the relationship between wholesale price and order volume such that the representative retailer expects zero profit is

$$
w_{B}=1-\frac{1+\lambda+\theta(1-\lambda)}{2(1+\theta)}\left(x_{A}+x_{B}\right),
$$

irrespective of the direction of parallel trade.

Using the same reasoning as above, it is easy to verify that the relationship in country $A$ between $w_{A}$ and $x_{A}+x_{B}$ is identical to (6). This means that the wholesale price in each country depends on the manufacturer's overall shipment only and that $w_{A}=w_{B}$. Of course, this is due to the assumption that parallel trade equalizes retail prices across countries. As a result, we can only determine the total volume of orders that maximizes the manufacturer's overall profit, $\Pi^{p t}=w_{B}\left(x_{A}+x_{B}\right)$, where $w_{B}$ is given by (6). It is easy to show that this overall profit is maximized for $\bar{w}_{B}=\frac{1}{2}$ irrespective of the expected demand in $B$. This results in an overall shipment of $\bar{X}=\frac{1+\theta}{(1+\lambda+\theta(1-\lambda))}$ and a manufacturer's overall profit of

$$
\Pi^{p t}=\frac{1+\theta}{2(1+\lambda+\theta(1-\lambda))} .
$$

Hence, comparing (2) and (7), we obtain

Result 1: The manufacturer's expected overall profit increases with parallel trade if demand in the low-demand state is not too low $\left(\theta>\frac{1-\lambda}{3-\lambda}\right)$ and decreases otherwise.

Figure 1 illustrates the manufacturer's total equilibrium profit as a function of $\theta$ with and without parallel trade. Except at $\theta=1$, parallel trade raises the manufacturer's profit when the retail price in $B$ remains positive even when demand is low (corresponding to $\theta>\frac{1-\lambda}{2-\lambda}$ in Figure 1). This is also the case when the retail price in $B$ drops to zero in the low-demand state, at least if $\theta>\frac{1-\lambda}{3-\lambda}$. The reason why parallel trade raises the manufacturer's profit can be seen most easily in the case where $\theta>\frac{1-\lambda}{2-\lambda}$. Since wholesale prices are the same with and without parallel trade, the increase in profit clearly comes from the fact that retailers overall order more inventory when parallel trade is authorized. The same effect is at work if $\frac{1-\lambda}{3-\lambda}<\theta<\frac{1-\lambda}{2-\lambda}$ : parallel trade gives retailers an incentive to order more inventory even without the manufacturer having to reduce the wholesale price (as he would do in this range without parallel trade). Finally, if $\theta<\frac{1-\lambda}{3-\lambda}-$ meaning that 


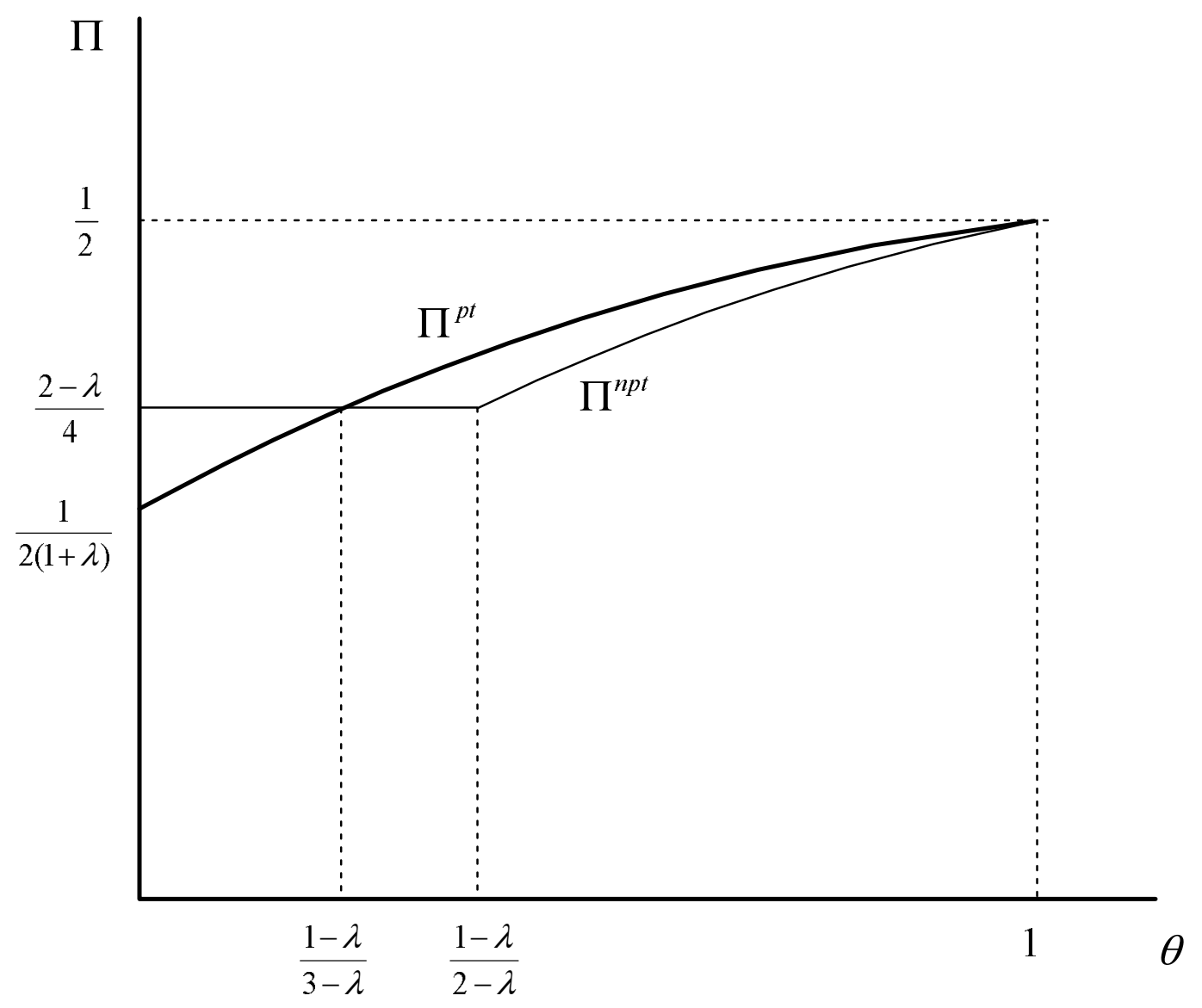

Figure 1: Manufacturer's total profit 
demand in $B$ in the low-demand state is extremely low - the effect of parallel trade on the overall level of inventory is exactly reversed. While still giving an incentive to retailers in $B$ to order more, this positive effect is more than offset by the fact that parallel trade gives a strong disincentive to retailers in $A$ who expect to be swamped with parallel imports when demand in $B$ is low. Hence, the manufacturer wants to prohibit parallel trade, precisely because he would ship too little inventory overall.

\subsection{Welfare}

We now investigate the welfare effects of allowing parallel trade, starting with the effect on consumer surplus. Suppose first that parallel trade is not allowed and let $C S_{i}^{n p t}$ denote the expected consumer surplus in country $i$ in this case. In country $A$, consumer surplus is $C S_{A}^{n p t}=\frac{1}{8}$. The expected domestic consumer surplus in $B$ is

$$
C S_{B}=\lambda\left(1-p_{B}^{l}\right) \frac{q_{B}^{l}}{2}+(1-\lambda)\left(1-p_{B}^{h}\right) \frac{q_{B}^{h}}{2} .
$$

The specific level of expected consumer surplus will depend on whether the retail price drops to zero when the state of the demand is low. If it does, using the respective prices and quantities in (8) yields $C S_{B}^{n p t}=\frac{4 \lambda \theta+1-\lambda}{8}$. If the retail price does not drop to zero, we obtain $C S_{B}^{n p t}=\frac{\theta}{8(\theta(1-\lambda)+\lambda)}$.

Suppose now that parallel trade is allowed, and let $C S_{i}^{p t}$ denote expected consumer surplus in country $i$. Above, we only found that $x_{A}+x_{B}=\bar{X}=$ $\frac{1+\theta}{(1+\lambda+\theta(1-\lambda))}$. Hence, we do not know the volume of orders from each country and the volume of parallel trade. To compute consumer surplus for each country, all we need, however, is individual country sales which can be found in the following way. Suppose demand in $B$ is low. Since parallel trade equalizes retail prices, it must be true that $1-\frac{q_{B}}{\theta}=1-q_{A}$ and thus $q_{A}=\frac{q_{B}}{\theta}$. In addition, parallel trade makes sure that, across the two countries, total sales must be equal to total orders (i.e., $q_{A}+q_{B}=x_{A}+x_{B}$ ). Combining these two conditions, we get

$$
q_{B}^{l}=\left(x_{A}+x_{B}\right) \frac{\theta}{1+\theta} \text { and } q_{B}^{h}=\frac{x_{A}+x_{B}}{2}
$$

when demand in $B$ is low, respectively high. Once we have computed retail 
prices in $B$, we can use (8) to obtain

$$
C S_{A}^{p t}=\frac{4 \lambda+(1-\lambda)(1+\theta)^{2}}{8(1+\lambda+\theta(1-\lambda))^{2}} \text { and } C S_{B}^{p t}=\frac{4 \lambda \theta+(1-\lambda)(1+\theta)^{2}}{8(1+\lambda+\theta(1-\lambda))^{2}} .
$$

A comparison of expected consumer surplus in the two countries with and without parallel imports yields the following result.

Result 2: Parallel trade raises expected consumer surplus in country A. It raises expected consumer surplus in country $B$ provided that the retail price is positive without parallel trade $\left(\theta \geq \frac{1-\lambda}{2-\lambda}\right)$, and reduces it otherwise.

When the demand is very low in the low-demand state, the retail price in $B$ drops to zero, and this can only benefit consumers. Allowing parallel trade makes this possibility less likely and this effect is detrimental to consumers. However, parallel trade also induces retailers to place larger orders, which is good for consumers. It is this effect that explains why consumer surplus in $B$ is higher with parallel trade when $\theta$ is high enough to guarantee positive retail prices in all states of demand. Since the retail price never drops to zero in $A$, this effect also explains why consumer surplus in $A$ always increases with parallel trade. Clearly, allowing parallel trade is profitable for the manufacturer exactly for the same reason that consumers in both countries like it, namely because retailers order more inventory - at least for sufficiently high values of $\theta$.

Finally we turn to world social welfare, $W$, which consists of the sum of consumer surplus and the manufacturer's profit (the retailers expect zero profit): $W=C S_{A}+C S_{B}+\Pi$. Figure 2 illustrates $W$ with and without parallel trade. We find:

Result 3: Parallel trade raises expected world welfare if $\theta$ is sufficiently high $\left(\theta \geq \frac{1-\lambda}{2-\lambda}\right)$ and reduces it otherwise.

The key insight is that the interests of consumers and the manufacturer are often aligned with the kind of parallel trade examined here: when demand shocks are not too large $\left(\theta \geq \frac{1-\lambda}{2-\lambda}\right)$, parallel trade raises both the manufacturer's profit and consumer surplus in both countries. This simple result is in sharp contrast with the conclusions of the literature viewing parallel trade as a price discrimination issue. Parallel trade in that literature typically produces a disagreement between consumers and producers on the one hand, and between consumers in different countries on the other (see Malueg and Schwartz, 1994). 


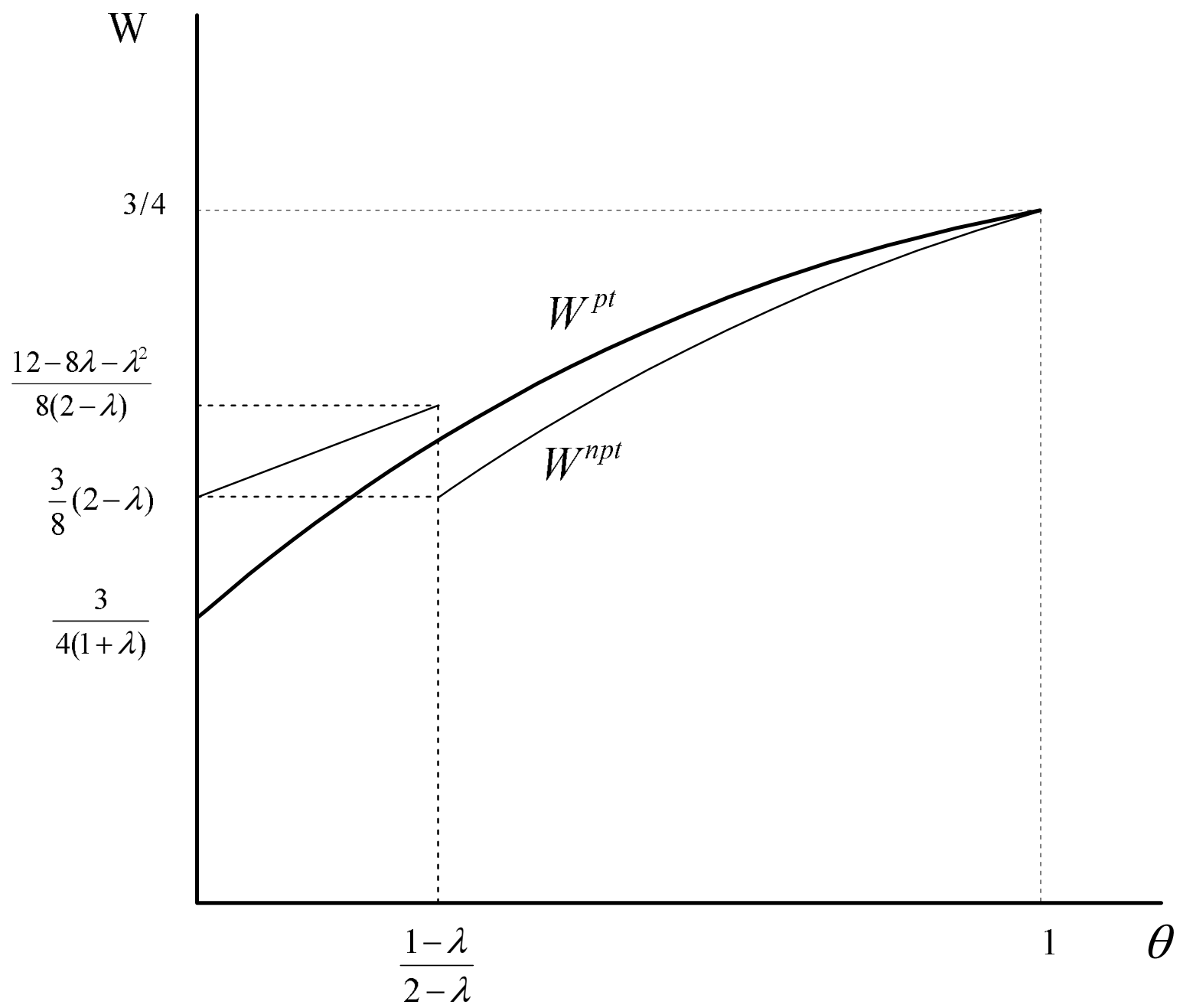

Figure 2: World social welfare 


\section{Generalization}

Consider now a more general specification of the demand and the distribution of the demand shock. Let demand in country $A$ be given by the function $D^{A}(p)$ and demand in $B$ by $D^{B}(p, \theta)$, with $D_{p}^{i}<0$, where $i=A, B$ and $\theta \in$ $\left[\theta^{-}, \theta^{+}\right]$is the (non-negative) realization of a random variable with density $f(\theta)$ and cumulative distribution $F(\theta)$. We still assume that in the presence of parallel trade prices are strictly positive for all realizations of demand. Note, however, that we no longer restrict the market in $B$ to be smaller than the one in $A$.

Writing the inverse demand functions as $p_{A}=p_{A}\left(q_{A}\right)$ and $p_{B}=p_{B}\left(q_{B}, \theta\right)$ and letting $m>0$ denote the volume of parallel trade going from $B$ to $A$, we can express the expected retail revenue in $A, E R_{A}^{r}$, as

$$
\begin{array}{ll}
\int_{\theta^{-}}^{\theta^{+}} p_{A}\left(x_{A}+m\right) x_{A} f(\theta) d \theta & \text { if } m \geq 0 \\
\int_{\theta^{-}}^{\theta^{+}}\left\{p_{A}\left(x_{A}+m\right)\left(x_{A}+m\right)+p_{B}\left(x_{B}-m, \theta\right)(-m)\right\} f(\theta) d \theta & \text { if } m<0
\end{array}
$$

and that in $B, E R_{B}^{r}$, as

$$
\begin{array}{ll}
\int_{\theta^{-}}^{\theta^{+}}\left\{p_{B}\left(x_{B}-m, \theta\right)\left(x_{B}-m\right)+p_{A}\left(x_{A}+m\right) m\right\} f(\theta) d \theta & \text { if } m \geq 0 \\
\int_{\theta^{-}}^{\theta^{+}} p_{B}\left(x_{B}-m, \theta\right) x_{B} f(\theta) d \theta & \text { if } m<0 .
\end{array}
$$

Since the expected retail profits, $E \pi_{i}^{r}=E R_{i}^{r}-w_{i} x_{i}, i=A, B$, must equal zero, we can write the manufacturer's problem of maximizing the expected value of $\Pi=w_{A} x_{A}+w_{B} x_{B}$ as

$$
\max _{x_{A}, x_{B}} \int_{\theta^{-}}^{\theta^{+}}\left\{p_{A}\left(x_{A}+m\right)\left(x_{A}+m\right)+p_{B}\left(x_{B}-m, \theta\right)\left(x_{B}-m\right)\right\} f(\theta) d \theta .
$$

The volume of parallel trade, $m=m\left(x_{A}, x_{B}, \theta\right)$, is the flow of goods that equalizes retail prices across the two countries ex post for each level of $x_{A}$, $x_{B}$ and $\theta$. It is implicitly defined by

$$
p_{A}\left(x_{A}+m\right)=p_{B}\left(x_{B}-m, \theta\right) .
$$

Suppose that the manufacturer's profit is maximized for $m=0$, and let the corresponding profit-maximizing order volumes be denoted by $x_{A}^{*}$ and $x_{B}^{*}$;

also assume, for the time being, that retail prices are non-negative at these 
volumes for all realizations of $\theta$. Then the derivative of (11) with respect to $m$ must be zero at $m=0$,

$$
\int_{\theta^{-}}^{\theta^{+}}\left\{p_{A}\left(x_{A}^{*}\right)+x_{A}^{*} p_{A}^{\prime}\left(x_{A}^{*}\right)-p_{B}\left(x_{B}^{*}, \theta\right)-x_{B}^{*} p_{B}^{\prime}\left(x_{B}^{*}, \theta\right)\right\} f(\theta) d \theta=0 .
$$

That is, the manufacturer will set wholesale prices ex ante so that the volumes ordered by the retailers, $x_{A}^{*}$ and $x_{B}^{*}$, equalize expected marginal revenues in $A$ and $B$. In addition, expected marginal revenues must equal marginal cost, which is zero,

$$
p_{A}\left(x_{A}^{*}\right)+x_{A}^{*} p_{A}^{\prime}\left(x_{A}^{*}\right)=\int_{\theta^{-}}^{\theta^{+}}\left\{p_{B}\left(x_{B}^{*}, \theta\right)+x_{B}^{*} p_{B}^{\prime}\left(x_{B}^{*}, \theta\right)\right\} f(\theta) d \theta=0 .
$$

Ex post, however, when the demand shock has been realized, marginal revenues may no longer be equalized for $x_{A}^{*}$ and $x_{B}^{*}$. That is, we may have

$$
M R_{A}^{*} \equiv\left(p_{A}\left(x_{A}^{*}\right)+x_{A}^{*} p_{A}^{\prime}\left(x_{A}^{*}\right)\right)=0 \gtrless p_{B}\left(x_{B}^{*}, \theta\right)+x_{B}^{*} p_{B}^{\prime}\left(x_{B}^{*}, \theta\right) \equiv M R_{B}^{*}(\theta) .
$$

In this case, an ex-post reallocation of output between markets would raise the manufacturer's expected profit. This can best be seen if we suppose that the manufacturer could do the reallocation himself, that is if distribution and production were vertically integrated. For realizations of $\theta$ for which $M R_{B}^{*}(\theta)>0$, the manufacturer would ship goods from $A$ to $B$ until marginal revenues are equalized, thereby raising his ex-post profit. When the realized value of $\theta$ is such that $M R_{B}^{*}(\theta)<0$, the manufacturer would not reallocate goods to $A$, but sell only enough units in $B$ to make marginal revenue there equal to zero, leaving some inventory unsold in the process. The ability to reallocate goods ex post would thus increase the manufacturer's profit for high values of $\theta$ and leave profit unchanged for low values. It follows that from an ex-ante perspective the manufacturer's expected profit would be higher if he had the option of reallocating goods ex post.

Of course, in the scenario we consider the goods have been sold to independent retailers. Hence the question is whether simply allowing them to engage in parallel trade can bring about an ex-post reallocation of goods that would raise the manufacturer's expected profit. The retailers will carry out parallel trade whenever there are differences in retail prices across countries. Retailers that can sell their goods in another country where prices are higher gain, those that see retail prices fall due to parallel imports lose. Will the 
aggregate retail profit in the two countries rise for a given realization of $\theta$ when parallel trade eliminates retail price differences? The answer is yes, if for the given $\theta$ the equalization of retail prices also moves marginal revenues closer to each other. Otherwise, aggregate retail profit for this value of $\theta$ falls.

To learn whether (ex-ante) expected aggregate retail profit rises or falls when parallel trade is allowed, one has to weight ex-post retail profits with the density and integrate over $\theta$. If the expected aggregate retail profit in $A$ and $B$ rises, then this implies that for given wholesale prices retailers have to order more inventory in order to keep the zero-profit constraint implied by perfect competition satisfied. This in turn means that the manufacturer's expected profit, expected consumer surplus (in the two countries taken together) and therefore also expected world welfare increase. By contrast, if the expected aggregate retail profit falls when parallel trade is allowed, then the manufacturer's expected profit, aggregate consumer surplus and world welfare decrease.

Therefore the crucial question is whether there exist sufficient conditions under which parallel trade raises expected aggregate retail profits and under which it lowers them. We prove the following result:

Proposition 1 (a) If $D^{A}(p)=D(p)$ and $D^{B}(p, \theta)=\theta D(p)$, and $F(\theta)$ puts sufficiently little probability mass on realizations of $\theta$ for which the retail price falls to zero without parallel trade, then allowing parallel trade raises the manufacturer's expected profit, expected world consumer surplus and expected world welfare. (b) If the inverse demand functions take the form $p_{A}=p(q)$ and $p_{B}=\theta p(q)$, then permitting parallel trade reduces the manufacturer's expected profit, expected world consumer surplus and expected world welfare.

Proof: (a) In this case, it is straightforward to show that the price elasticity of demand, $\varepsilon(p)$, does not depend on $\theta$. Hence marginal revenues in $A$ and $B$ are equalized ex post if

$$
p_{A}\left(1-\frac{1}{\varepsilon\left(p_{A}\right)}\right)=p_{B}\left(1-\frac{1}{\varepsilon\left(p_{B}\right)}\right),
$$

i.e. whenever $p_{A}=p_{B}$. Hence parallel trade, by equalizing retail prices for every value of $\theta$, must raise expected aggregate retail profits. This is true under the implicit assumption that in the absence of parallel trade retail prices are non-negative for all realizations of demand. 
Suppose now that without parallel trade the choice of $x_{A}^{*}$ and $x_{B}^{*}$ causes the retail price in $B$ to drop to zero for low realizations of demand. In particular, let $\tilde{\theta} \equiv \tilde{\theta}\left(x_{B}^{*}\right)$ be defined by $p_{B}\left(\frac{x_{B}^{*}}{\tilde{\theta}}\right)=0$, so that price is zero for $\theta \in\left[\theta^{-}, \tilde{\theta}\right] .{ }^{9}$ We then have to modify (14) as follows:

$$
p_{A}\left(x_{A}^{*}\right)+x_{A}^{*} p_{A}^{\prime}\left(x_{A}^{*}\right)=\int_{\tilde{\theta}}^{\theta^{+}}\left\{p_{B}\left(\frac{x_{B}^{*}}{\theta}\right)+\frac{x_{B}^{*}}{\theta} p_{B}^{\prime}\left(\frac{x_{B}^{*}}{\theta}\right)\right\} f(\theta) d \theta=0 .
$$

For any $\theta \in\left[\theta^{-}, \tilde{\theta}\right]$, goods will flow from $B$ to $A$ if we allow parallel trade. This will have no effect at first on retailer profits in $B$ because the price there is zero. The retailer profits in $A$, however, must fall as successive units are shipped there, since $x_{A}^{*}$ was chosen optimally and additional units cause marginal revenue to become negative. Thus parallel trade may lower ex-post aggregate retail profit for low values of $\theta$. For $\theta \in\left(\tilde{\theta}, \theta^{+}\right]$parallel trade will raise overall ex-post retail profit for the reasons given in the preceding paragraph. Hence the overall effect of parallel trade will depend on the distribution of $\theta$. In particular, if there is sufficiently little probability mass on $\left[\theta^{-}, \tilde{\theta}\right]$, the expected aggregate retail profit will increase with parallel trade.

(b) In this case one can easily show that an equalization of marginal revenues requires equal shipments to each market independent of $\theta$,

$$
p\left(x_{A}\right)\left(1-\frac{1}{\varepsilon\left(x_{A}\right)}\right)=p\left(x_{B}\right)\left(1-\frac{1}{\varepsilon\left(x_{B}\right)}\right),
$$

and hence almost always results in different retail prices. Allowing retailers to engage in parallel trade necessarily pushes marginal revenues apart in the two countries for every value of $\theta$ and hence reduces expected aggregate retail profit.

The proposition shows that the form of demand uncertainty plays a crucial role in determining whether parallel trade is desirable or not. ${ }^{10}$ One way

\footnotetext{
${ }^{9}$ Note that we let $p_{B}=p_{B}\left(\frac{q_{B}}{\theta}\right)$ be the inverse of $D_{B}(p, \theta)=\theta D(p)$.

${ }^{10}$ The proposition does not depend on whether the retailing sector is perfectly competitive or not. Consider the other extreme of a single retailer in each country. If the realization of $\theta$ produces different retail prices, the marginal revenue of the retailer located in the low-price market on the first unit shipped to the high price market is equal to the retail price in that market (and thus necessarily higher than the marginal revenue of selling this unit in his home market). Not surprisingly this means that the flow of parallel trade goes in the same direction as in the presence of a competitive retailing sector. More importantly, this implies that parallel trade raises (lowers) the manufacturer's expected
} 
to interpret the demand shock in (a) is to assume that consumers in both countries have identical individual demand functions, but that the manufacturer does not know how many consumers there will be for his product. Hence, at any given price, the price elasticity of demand is the same across the two countries, but the manufacturer does not know how much he will sell at that price. Both manufacturers and retailers have the same incentives with respect to parallel trade: let retailers ship goods ex post to the market where demand is highest so that it pays them to order more inventory. Case (b) can be viewed as a situation in which consumers in the two countries differ in their willingness to pay, but the manufacturer is uncertain about how much they differ. This situation requires that the retail price of the good adjusts ex post to the realized willingness to pay. Without parallel trade, perfect competition between retailers ensures that this adjustment takes place. Parallel trade, however, interferes with this price adjustment because a rise in the retail price tends to draw parallel imports into the country. In anticipation of this, retailers will order less inventory, thereby reducing the manufacturer's profit, as well as consumer surplus and welfare.

\section{Conclusions}

This paper demonstrates that there are circumstances under which it pays a manufacturer to allow retailers to engage in parallel trade. Specifically, parallel trade gives retailers an incentive to place larger orders than they otherwise would. Moreover, parallel trade in these circumstances is generally welfare improving. These results arise when four conditions are met: first, retailers must place orders before they know the state of the demand; second, the states of the demand are different across markets; third, the products have little value at the end of the demand period (or equivalently, it is costly to maintain them as inventories); and fourth, we have the right type of demand shock. In particular, we should expect to see parallel imports encouraged by manufacturers in those industries in which consumers' willingness to pay is relatively similar across markets but for which there is uncertainty about how many consumers will actually choose to buy. In short, these would be products that are relatively standard but for one reason or another the

profit with case-a (case-b) demand shocks. The same line of argument can be applied if we have oligopolisitc retailers in each country: we only need to reinterpret marginal revenue as residual marginal revenue to get the same results. 
manufacturers have a difficult time anticipating the volume of sales. The toy market seems like a good example of such market, but so are certain segments of the fashion, motorcycle or even automobile markets, as well as the electronics market to name just a few. In all these cases, we expect parallel imports to change direction or at least to vary widely in volumes from year to year. This is the case, for instance, in the North American automobile market where the volume of parallel trade between Canada and the US is today a fraction of what it was a few years ago (Automotive News, $2004 \mathrm{~b}$ ). The same is true in the US market of earth-moving equipment where, as a result of the Asian crisis, the gray market share rose from $4.7 \%$ in 1997 to $19.5 \%$ in 1998 (Business Week, 1998).

It is important to note that there are other possible mechanisms that would allow a manufacturer to reduce destructive competition. Three come to mind: vertical integration with retailers, resale price maintenance (see Deneckere et al., 1997), or a return policy for unsold inventories. The point of the paper is that parallel trade constitutes a particularly simple mechanism to achieve this goal. We would expect this to be true, especially if the manufacturer has less information than retailers about local market conditions, as seems especially likely if the manufacturer is located overseas. Resale price maintenance, for instance, would involve considerably more checking and monitoring of retailers than allowing parallel imports. Similarly a manufacturer's return policy is costly, not only because it might allow well informed local retailers to shirk on sales effort, but also because a foreign manufacturer may have no particular physical facilities in its export markets to handle returned merchandise. Finally, vertical integration may be difficult for a foreign manufacturer again due to informational asymmetries, but also because the market volume may be too small to justify the investment.

\section{References}

[1] Ahmadi, Reza and Rachel Yang. 2000. 'Parallel Imports: Challenges from Unauthorized Distribution Channels'. Marketing Science 19 (3), 279-94.

[2] Automotive News. 2004a. 'No Matter What Color that Lexus is Asia Quite Often Is Gray'. 78, Issue 6078, February 2. 
[3] Automotive News. 2004b. 'Once-sizzling Canadian Import Market Loses Steam'. 79, Issue 6109, August 30.

[4] Automotive News. 2002. 'Gray Market Yields Gold'. 76, Issue 5972, February 25.

[5] Business Week. 1998. 'The Earth is Shifting under Heavy Equipment'. Issue 3572, April 6.

[6] Cespedes, F.; E.R. Corey abd V.K. Rangan. 1988. 'Gray Markets: Causes and Cures'. Harvard Business Review, July-August, 75-82.

[7] Computer Reseller News. 2001. 'Vendors Aim to Squash Gray Market'. Issue 963, September 17.

[8] Cosac, Teodora. 2002. 'Vertical Restraints and Parallel Imports with Differentiated Products'. Unpublished PhD Thesis, Simon Fraser University.

[9] Deneckere, Raymond, Howard P. Marvel and James Peck. 1997. 'Demand Uncertainty and Price Maintenance: Markdowns as Destructive Competition'. American Economic Review 87, 4, 619-41.

[10] Financial Post. 2001. 'Wanted: Canadian Cars'. November 3, 2001

[11] Gallini, Nancy and Aiden Hollis. 1999. 'A Contractual Approach to the Gray Market'. International Review of Law and Economics, 19(1), 1-21.

[12] House of Commons. 1999. Trademarks, Fakes and Consumers. Eight Report, Trade and Industry Committee. http://www.parliament.the -stationery-office.co.uk/ pa/cm199899/cmselect/ cmtrdind/380/38007.htm

[13] Knox, Daniel and Martin Richardson. 2002. 'Trade Policy and Parallel Imports'. European Journal of Political Economy 19, 133-51.

[14] Lipner, Seth. 1990. The Legal and Economic Aspects of Gray Market Goods. London: Quorum Books.

[15] Malueg, D.A. and Marius Schwartz. 1994. 'Parallel Imports, Demand Dispersion and International Price Discrimination'. Journal of International Economics 37, 167-96. 
[16] Maskus, Keith and Yongmin Chen. 2002. 'Parallel Imports in a Model of Vertical Distribution: Theory, Evidence and Policy'. Pacific Economic Review 7(2), 319-34.

[17] Maskus, Keith. 2000. Parallel Imports. World Economy 23, 9. 1269-84.

[18] NERA. 1999. 'The Economic Consequences of the Choice of a Regime of Exhaustion in the Area of Trademarks'. Final report for DGXV of the European Commission, February.

[19] Richardson, Martin. 2002. 'An Elementary Proposition Concerning Parallel Imports'. Journal of International Economics 56, 1, 233-45.

[20] Tirole, Jean. 1988. The Theory of Industrial Organization. Cambridge: MIT Press.

[21] World IT Report. 2003. '30 Percent of Malaysian Cells Purchased Through Grey Market'. December 28. 


\section{CESifo Working Paper Series}

(for full list see www.cesifo-group.de)

1437 Martin Kolmar and Volker Meier, Intra-Generational Externalities and InterGenerational Transfers, March 2005

1438 M. Hashem Pesaran and Takashi Yamagata, Testing Slope Homogeneity in Large Panels, March 2005

1439 Gjermund Nese and Odd Rune Straume, Industry Concentration and Strategic Trade Policy in Successive Oligopoly, April 2005

1440 Tomer Blumkin and Efraim Sadka, A Case for Taxing Education, April 2005

1441 John Whalley, Globalization and Values, April 2005

1442 Denise L. Mauzerall, Babar Sultan, Namsoug Kim and David F. Bradford, Charging $\mathrm{NO}_{x}$ Emitters for Health Damages: An Exploratory Analysis, April 2005

1443 Britta Hamburg, Mathias Hoffmann and Joachim Keller, Consumption, Wealth and Business Cycles in Germany, April 2005

1444 Kohei Daido and Hideshi Itoh, The Pygmalion Effect: An Agency Model with Reference Dependent Preferences, April 2005

1445 John Whalley, Rationality, Irrationality and Economic Cognition, April 2005

1446 Henning Bohn, The Sustainability of Fiscal Policy in the United States, April 2005

1447 Torben M. Andersen, Is there a Role for an Active Fiscal Stabilization Policy? April 2005

1448 Hans Gersbach and Hans Haller, Bargaining Power and Equilibrium Consumption, April 2005

1449 Jerome L. Stein, The Transition Economies: A NATREX Evaluation of Research, April 2005

1450 Raymond Riezman, John Whalley and Shunming Zhang, Metrics Capturing the Degree to which Individual Economies are Globalized, April 2005

1451 Romain Ranciere, Aaron Tornell and Frank Westermann, Systemic Crises and Growth, April 2005

1452 Plutarchos Sakellaris and Focco W. Vijselaar, Capital Quality Improvement and the Sources of Growth in the Euro Area, April 2005

1453 Kevin Milligan and Michael Smart, Regional Grants as Pork Barrel Politics, April 2005 
1454 Panu Poutvaara and Andreas Wagener, To Draft or not to Draft? Efficiency, Generational Incidence, and Political Economy of Military Conscription, April 2005

1455 Maurice Kugler and Hillel Rapoport, Skilled Emigration, Business Networks and Foreign Direct Investment, April 2005

1456 Yin-Wong Cheung and Eiji Fujii, Cross-Country Relative Price Volatility: Effects of Market Structure, April 2005

1457 Margarita Katsimi and Thomas Moutos, Inequality and Relative Reliance on Tariffs: Theory and Evidence, April 2005

1458 Monika Bütler, Olivia Huguenin and Federica Teppa, Why Forcing People to Save for Retirement may Backfire, April 2005

1459 Jos Jansen, The Effects of Disclosure Regulation of an Innovative Firm, April 2005

1460 Helge Bennmarker, Kenneth Carling and Bertil Holmlund, Do Benefit Hikes Damage Job Finding? Evidence from Swedish Unemployment Insurance Reforms, May 2005

1461 Steffen Huck, Kai A. Konrad and Wieland Müller, Merger without Cost Advantages, May 2005

1462 Louis Eeckhoudt and Harris Schlesinger, Putting Risk in its Proper Place, May 2005

1463 Hui Huang, John Whalley and Shunming Zhang, Trade Liberalization in a Joint Spatial Inter-Temporal Trade Model, May 2005

1464 Mikael Priks, Optimal Rent Extraction in Pre-Industrial England and France - Default Risk and Monitoring Costs, May 2005

1465 François Ortalo-Magné and Sven Rady, Heterogeneity within Communities: A Stochastic Model with Tenure Choice, May 2005

1466 Jukka Pirttilä and Sanna Tenhunen, Pawns and Queens Revisited: Public Provision of Private Goods when Individuals make Mistakes, May 2005

1467 Ernst Fehr, Susanne Kremhelmer and Klaus M. Schmidt, Fairness and the Optimal Allocation of Ownership Rights, May 2005

1468 Bruno S. Frey, Knight Fever - Towards an Economics of Awards, May 2005

1469 Torberg Falch and Marte Rønning, The Influence of Student Achievement on Teacher Turnover, May 2005

1470 John Komlos and Peter Salamon, The Poverty of Growth with Interdependent Utility Functions, May 2005 
1471 Hui Huang, Yi Wang, Yiming Wang, John Whalley and Shunming Zhang, A Trade Model with an Optimal Exchange Rate Motivated by Current Discussion of a Chinese Renminbi Float, May 2005

1472 Helge Holden, Lars Holden and Steinar Holden, Contract Adjustment under Uncertainty, May 2005

1473 Kai A. Konrad, Silent Interests and All-Pay Auctions, May 2005

1474 Ingo Vogelsang, Electricity Transmission Pricing and Performance-Based Regulation, May 2005

1475 Spiros Bougheas and Raymond Riezman, Trade and the Distribution of Human Capital, June 2005

1476 Vesa Kanniainen, Seppo Kari and Jouko Ylä-Liedenpohja, The Start-Up and Growth Stages in Enterprise Formation: The "New View" of Dividend Taxation Reconsidered, June 2005

1477 M. Hashem Pesaran, L. Vanessa Smith and Ron P. Smith, What if the UK had Joined the Euro in 1999? An Empirical Evaluation Using a Global VAR, June 2005

1478 Chang Woon Nam and Doina Maria Radulescu, Effects of Corporate Tax Reforms on SMEs' Investment Decisions under the Particular Consideration of Inflation, June 2005

1479 Panos Hatzipanayotou, Sajal Lahiri and Michael S. Michael, Globalization, CrossBorder Pollution and Welfare, June 2005

1480 John Whalley, Pitfalls in the Use of Ad valorem Equivalent Representations of the Trade Impacts of Domestic Policies, June 2005

1481 Edward B. Barbier and Michael Rauscher, Trade and Development in a Labor Surplus Economy, June 2005

1482 Harrie A. A. Verbon and Cees A. Withagen, Tradable Emission Permits in a Federal System, June 2005

1483 Hendrik Hakenes and Andreas Irmen, On the Long-Run Evolution of Technological Knowledge, June 2005

1484 Nicolas Schmitt and Antoine Soubeyran, A Simple Model of Brain Circulation, June 2005

1485 Carsten Hefeker, Uncertainty, Wage Setting and Decision Making in a Monetary Union, June 2005

1486 Ondřej Schneider and Jan Zápal, Fiscal Policy in New EU Member States - Go East, Prudent Man!, June 2005

1487 Christian Schultz, Virtual Capacity and Competition, June 2005 
1488 Yvan Lengwiler and Elmar Wolfstetter, Bid Rigging - An Analysis of Corruption in Auctions, June 2005

1489 Johannes Becker and Clemens Fuest, Does Germany Collect Revenue from Taxing Capital Income?, June 2005

1490 Axel Dreher and Panu Poutvaara, Student Flows and Migration: An Empirical Analysis, June 2005

1491 Bernd Huber and Marco Runkel, Interregional Redistribution and Budget Institutions under Asymmetric Information, June 2005

1492 Guido Tabellini, Culture and Institutions: Economic Development in the Regions of Europe, July 2005

1493 Kurt R. Brekke and Michael Kuhn, Direct to Consumer Advertising in Pharmaceutical Markets, July 2005

1494 Martín Gonzalez-Eiras and Dirk Niepelt, Sustaining Social Security, July 2005

1495 Alfons J. Weichenrieder, (Why) Do we need Corporate Taxation?, July 2005

1496 Paolo M. Panteghini, S-Based Taxation under Default Risk, July 2005

1497 Panos Hatzipanayotou and Michael S. Michael, Migration, Tied Foreign Aid and the Welfare State, July 2005

1498 Agata Antkiewicz and John Whalley, BRICSAM and the Non-WTO, July 2005

1499 Petr Hedbávný, Ondřej Schneider and Jan Zápal, A Fiscal Rule that has Teeth: A Suggestion for a 'Fiscal Sustainability Council' underpinned by the Financial Markets, July 2005

1500 J. Atsu Amegashie and Marco Runkel, Sabotaging Potential Rivals, July 2005

1501 Heikki Oksanen, Actuarial Neutrality across Generations Applied to Public Pensions under Population Ageing: Effects on Government Finances and National Saving, July 2005

1502 Xenia Matschke, Costly Revenue-Raising and the Case for Favoring Import-Competing Industries, July 2005

1503 Horst Raff and Nicolas Schmitt, Why Parallel Trade may Raise Producers Profits, July 2005 